\title{
Resilience in Pre-Columbian Caribbean House-Building: Dialogue Between Archaeology and Humanitarian Shelter
}

\author{
A. V. M. Samson ${ }^{1}$ - C. A. Crawford ${ }^{2}$ - M. L. P. Hoogland ${ }^{3}$ - C. L. Hofman ${ }^{3}$
}

Published online: 23 April 2015

(C) The Author(s) 2015. This article is published with open access at Springerlink.com

\begin{abstract}
This paper responds to questions posed by archaeologists and engineers in the humanitarian sector about relationships between shelter, disasters and resilience. Enabled by an increase in horizontal excavations combined with highresolution settlement data from excavations in the Dominican Republic, the paper presents a synthesis of Caribbean house data spanning a millennium (1400 BP- $450 \mathrm{BP})$. An analysis of architectural traits identify the house as an institution that constitutes and catalyses change in an emergent and resilient pathway. The "Caribbean architectural mode" emerged in a period of demographic expansion and cultural transition, was geographically widespread, different from earlier and mainland traditions and endured the hazards of island and coastal ecologies. We use archaeological analysis at the house level to consider the historical, ecological and regional dimensions of resilience in humanitarian action
\end{abstract}

Keywords Pre-Columbian Caribbean · Resilience .

House architecture $\cdot$ Humanitarian shelter .

Environmental hazards

A. V. M. Samson

avms2@cam.ac.uk

1 University of Cambridge, Cambridge, Cambridgeshire, UK

2 Centre for Urban Sustainability and Resilience, Department of Civil Engineering and Geomatic Engineering, University College London, London, UK

3 Faculty of Archaeology, Leiden University, Leiden, The Netherlands

\section{Introduction}

Archaeologists and international humanitarian organisations are both involved in recovery: The former do this for the past, and the latter for the present. This paper suggests that examination of patterns in the regional archaeological record may reveal some useful implications for dealing with post-disaster shelter relief in the Caribbean and further afield.

The archaeological analysis offered here identifies shared domestic building practices that spanned the islands of the Caribbean archipelago and coalesced into a specific architectural mode. By analysing pre-Columbian house structures from the perspective of environmental and hazard response and distinguishing island house features from those of the mainland, we show the specific ways in which climate change, perceptions of risk, and weather regimes are incorporated within the structure of the house. The material evidence shows the ways in which indigenous Caribbean societies developed house- building practices suited to maritime ecologies and hazards, and which endured over long periods of time. An archaeological perspective on long-range regional change could enhance humanitarian efforts to respond to contemporary physical hazards. In turn, of course, an awareness of humanitarian approaches to alleviating disasters emphasises the agency and hazard resilience of households and enriches archaeological analysis.

Charles Redman (2012), drawing on the work of geographers and resilience theorists, identifies building technology as an important and perennial domain of problem-solving strategies that people use to cope with challenges to their social and physical environment. Elsewhere, in addressing resilience Redman and Kinzig (2003) highlight how institutions that mediate human-environmental interactions emerge, what influences their character, and their effectiveness in mitigating the consequences of natural or man-made disasters. 
We follow these approaches in examining houses and households as institutions at the frontline of resilience strategies.

Turning briefly to international humanitarian disaster relief it seems that "-providing adequate shelter is one of the most intractable problems in international humanitarian response" (HERR 2011). A primary problem is the tendency to focus narrowly on supplying shelter-related products and replacing physical assets (Bhattacharjee et al. 2007; Da Silva 2010:3) rather than on supporting people in rebuilding with locally appropriate building practices (Langenbach 2009; Langenbach et al. 2010; Langenbach et al. 2006). A second problem is the formal separation - through funding streams and organisational structures - of humanitarian activities into sectors (Pain and Levine 2012), which disconnects shelter and housing from other fields of action affecting the household (Crawford 2011).

Similarly, in terms of timeframes, international responses separate funding streams and participant organisations into two distinct phases: emergency response and longer term recovery development (Pain and Levine 2012). This, combined with an immediate, singular focus on the area directly affected by the current disaster, contributes to the tendency to overlook longer term or systemic issues (Burnell and Sanderson 2011; Clermont et al. 2011; Crawford 2011) as well as the broader environmental context (Davis 2011). The International Federation of the Red Cross (IFRC), an entity charged with coordinating shelter relief after natural disasters, describes recovery as including"-a process of 'sheltering' done by affected households with different materials, technical, financial and social assistance....". However, the literature on disaster response suggests that in reality the humanitarian relief often fails to relate to practicalities of livelihood and social and economic life (Davis 2011; Lyons et al. 2011; Schilderman and Lyons 2011). The structural separation of sectors and timeframes is exacerbated by conceptual simplifications of the shelter recovery pathway. Figure 1 shows this as a series of incremental improvements that happen only to the postdisaster 'shelter object' on a single trajectory. This largely ignores the pre-disaster role of people as the agents of change or stasis and assumes a theory of change that depends on a single forward trajectory based on incremental change to the shelter object, ignoring prior, inexplicable or cyclic changes that are in train before and continue after humanitarian history begins at the moment of disaster (Crawford et al. 2013).

The assertion that "shelter must be considered as a process not as an object" is not new (Davis 1978: 6), but the romantic appeal of vernacular architecture can mask the messy, 'unsentimental resourcefulness' of ordinary building (Richards 2012). Humanitarian narratives of livelihoods and operational standards tend to the normative and prescriptive, giving preeminence to

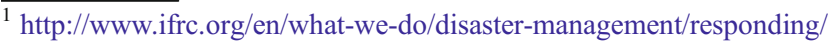
services-for-the-disaster-affected/shelter-and-settlement/how-we-doshelter/
}

the 'existing', 'appropriate' and 'local' (Sphere 2004) without curiosity as to how these have come about (TEC 2006).

Archaeological perspectives indicate that "....More frequent and more sudden hazards are often prominently encoded in local knowledge“ (Redman 2012:238) and offer a method for viewing this on a broad geographic scale and for a significant period of time (Cooper 2012).

\section{Historical Maritime Ecologies and Caribbean Domestic Architecture}

The diversity of island landscapes across the Caribbean archipelago is unified by a shared maritime climate, diurnal variation in wind and temperature, and periodic dramatic climatic and seismic events. Hurricanes, tropical storms, tsunamis and to a less frequent extent earthquakes and volcanoes are a regular experience of Caribbean peoples past and present (Bérard et al. 2001; Delpuech 2004; Hofman and Hoogland 2015; Fitzpatrick 2011; Petitjean Roget 2001; Pielke et al. 2003; Roobol and Smith 2004; Scheffers et al. 2005). From a long-term perspective, paleoclimatic records show that there were significant changes in climatic conditions throughout the Late Holocene in which centuries-long cycles of wetter, stormy conditions were interspersed with drier conditions and sea-level rise (Beets et al. 2006; Cooper 2013; Hodell and Curtis 1991; Donnelly and Woodruff 2007; Malaizé et al. 2011). Archaeological research has shown climatic variation had a significant local impact on settlements which led to site abandonment and repeated flooding (Hofman and Hoogland 2015; Fitzpatrick 2011; Rodríguez Ramos 2010:188).

From the time of initial human colonisation of the archipelago ca. $7500 \mathrm{BP}$, peoples in the islands adapted to maritime ecosystems and weather regimes markedly different from the continent of South America. Human habitation and exploitation of island environments impacted local ecosystems, including direct and indirect introduction of exotic plants and animals and forest clearance creating increasingly open, agricultural landscapes, intensifying from 2500BP. Caribbean peoples relied on a diversity of marine, wild and cultivated foods and settled the majority of the Antillean archipelago, including small islands (Boomert 1999; Fitzpatrick and Keegan 2007; Hofman 2013; Keegan et al. 2008; Veloz Maggiolo 1991). Caribbean communities were involved in intensive local and regional networks of human mobility and exchange of goods and ideas since first colonisation of the islands (Hofman and Bright eds 2010).

\section{Regional Narratives: Transformation of the Household Driving Regional Social and Political Change}

From 1400BP/AD600 changes in material culture, and the organisation of the landscape, which included the 


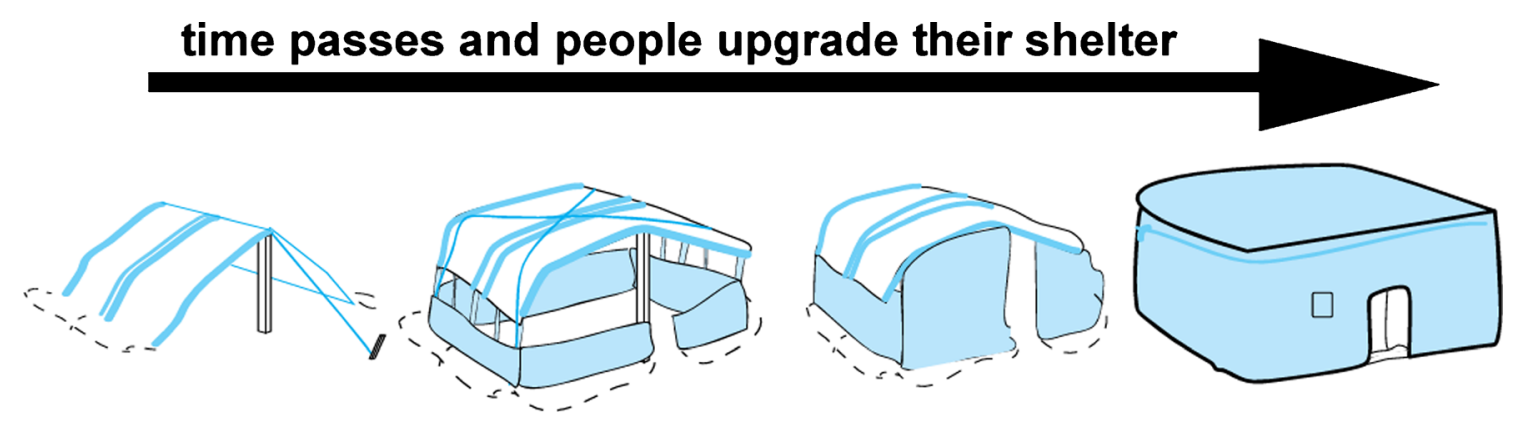

Fig. 1 Illustration of the humanitarian shelter process showing incremental upgrades to individual post-disaster shelters (based on UNOCHA 2004)

development of settlement hierarchies and ceremonial centres in the Greater Antilles and Virgin islands, have been interpreted as social and political transformations as a result of migrations, the emergence of new and local networks, and environmental change. These changes, which mark the transition to the period known as the Late Ceramic Age, also coincide with the moment in which indigenous house plans first become archaeologically visible. Transformations at the household level such as a proposed shift from communal to lineage-based society in the Greater Antilles, changes in land tenure and heritable property, and a greater investment in place were apparently some of the driving forces behind these higher level changes (Curet and Oliver 1998; Torres 2012; Veloz Maggiolo 1984).

\section{Archaeological Context}

Data needed to make regional or even intra-site comparisons of Caribbean domestic structures were lacking until the last decade. A synthesis of data from excavated structures suggests it is within the post-1400BP cultural and ecological context that we first recognise the emergence of a "Caribbean architectural mode." The perishable nature of indigenous construction materials and the vulnerability of cultural heritage in the Caribbean complicate the recovery of settlement features (Curet 1992:161; Siegel and Righter 2011; Hofman et al. 2012). Instead, information on domestic life and house structures has been inferred from areas with different, continental ecologies and below the hurricane boundary, or from European descriptions in colonial texts. Sixteenth-century sketches and recollections of house structures on Hispaniola (Haiti and the Dominican Republic) the Bahamas, and Cuba (Fernández de Oviedo y Valdéz 1851; Las Casas 1875) describe houses resembling straw huts or tents, with status differences marked by house size, and irregularly laid-out in settlements consisting of one to several thousand structures. These sources refer to a short window following European discovery and conquest in which descriptions unfavourably ranked native technologies against supposedly superior European design. The colonizer's perspective emphasized expediency and insubstantiality, which, as we shall see, does not correspond to the long-term, material evidence from archaeology.

Archaeologists supplemented this picture with ethnographic data from lowland South America. One model commonly used as a template for ancient or pre-1400BP Caribbean houses is the maloca, or community house, a large, single-dwelling that housed the whole village, up to $40 \mathrm{~m}$ in diameter and $30 \mathrm{~m}$ in height, often with fully closed walls. This was formerly the dominant type of settlement in Amazonia and the Guianas (Boomert 2000: 283; Versteeg and Schinkel 1992). Other types of traditional tropical settlement include individual family houses around a central clearing, and linear villages along river channels (Boomert 2000; Heckenberger and Petersen 1995; Schinkel 1992; Siegel 1992, 1996).

\section{Recent Archaeological Excavations}

A review of more recent archaeological excavations reveals a substantial dataset of complete domestic structures. Most have been recovered from the period post-1100BP from the larger Caribbean landmasses, especially Puerto Rico, with others on Cuba, the Turks and Caicos Islands, Jamaica and St Thomas, U.S. Virgin Islands, and fewer from the Lesser Antilles. ${ }^{2}$ This paper concentrates on sites with published structure plans from the Greater Antilles, Turks and Caicos, Virgin Islands, and northern Lesser Antilles (Fig. 2). We exclude the southern Lesser Antilles due to current data limitations (but see Hofman and Hoogland 2012), and Trinidad and Tobago and the southern offshore islands because they are south of the common hurricane boundary. The analysis is supplemented with a number of incomplete domestic structures from other sites

\footnotetext{
${ }^{2}$ Carlson 2007; Curet 1992; Delpuech et al. 1997; Drewett and Bennell 2000; Goodwin et al. eds. 2003; Hofman et al. 2012; Hofman and Hoogland 1999; Hofman and Hoogland 2010; Hoogland and Hofman 1993; Hoogland 1996; Jansen and Dorst 2007; Jardines Macías and Calvera Rosés 1999; Kaplan 2009; Meléndez Maíz 1996; Pendergast et al. 2002, 2003; Righter 2002; Rivera and Pérez 1997; Rivera and Rodríguez 1991; Schinkel 1992; Siegel 1989, 1992; Sullivan 1981 in Keegan 2007; Rojas et al. 2006; Van den Bel and Romon 2010; Versteeg and Rostain eds. 1997; Walker 2005.
} 


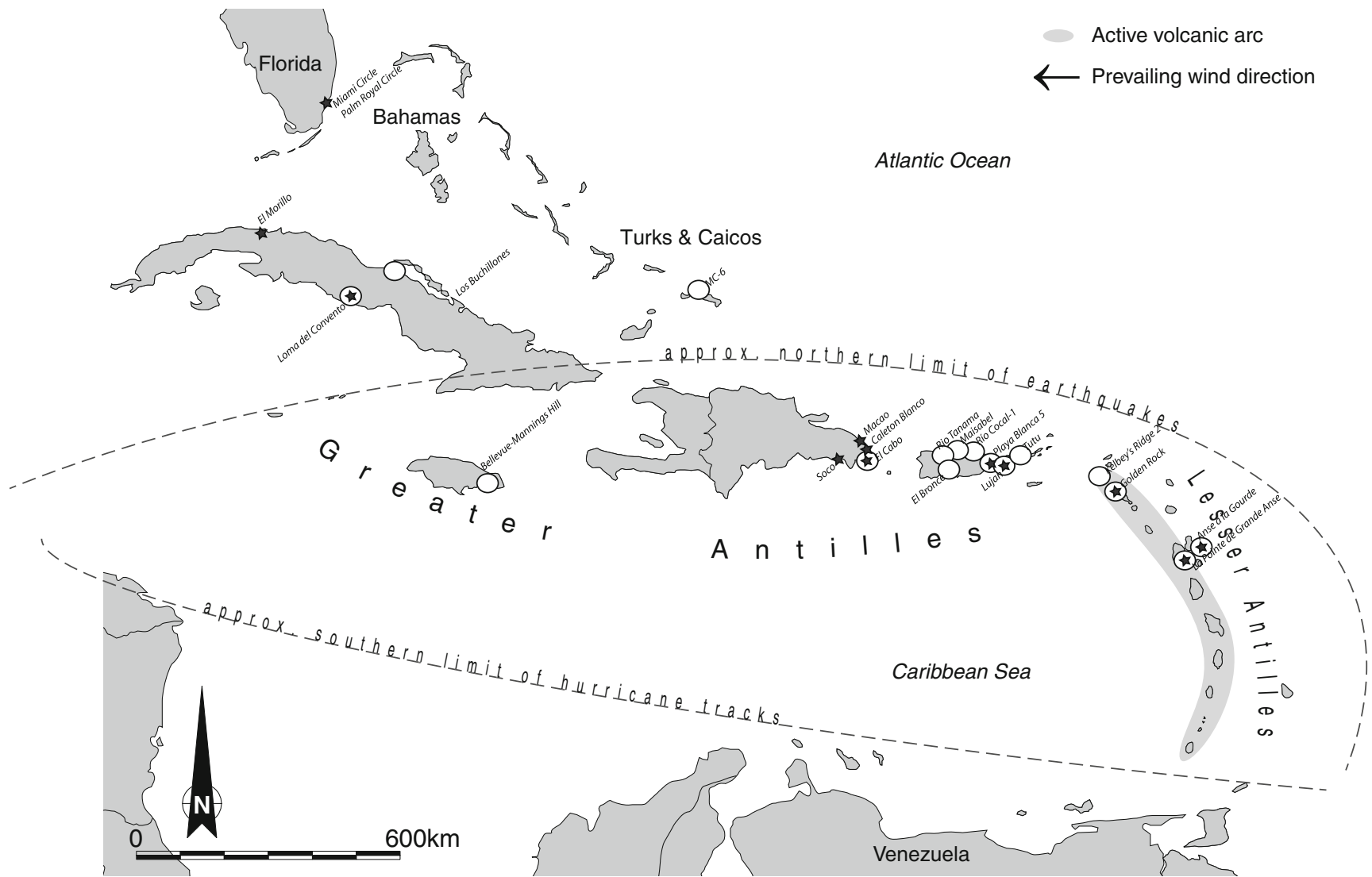

Fig. 2 Map of Caribbean with sites in Tables 1 and 2 and environmental characteristics. Sites with complete archaeological plans (white dots) and use of bedrock for structure foundations (black stars)

and regions by virtue of the shared building choices apparent in their archaeological plans.

Table 1 presents 16 sites across the Caribbean for which ca. 150 structures have been published. Individual sites frequently demonstrate a palimpsest of multiple centuries of habitation, although the lack of radiocarbon dates from house features provides little intra-site chronological control. Structures date from 1400BP to 450BP, or from the start of the Late Ceramic Age expansion up to European colonization, with most evidence available from 1100BP onwards. Around 80 of these structures have been interpreted as houses (as opposed to mortuary, ancillary or boundary structures). Site types range from isolated structures perhaps representing seasonal or garden houses, such as Playa Blanca 5, multiple households such as Kelbey's Ridge 2, to large settlements, or towns, ${ }^{3}$ such as El Cabo and Tutu. The number of structures per site is a reflection of the size of the excavated area rather than the settlement size. Not all sites yielded equally reliable plans nor all publications sufficient detail, and the discussions below

\footnotetext{
3 The term "town" is used to express comparative population size with settlements in Europe. Indigenous towns were socially, economically and administratively distinct from Old World models.
}

rely to a certain extent on interpretive bootstrapping from data from sites such as El Cabo, Tutu and Anse à la Gourde for which multiple structures are available (Hofman et al. 2001; Righter 2002; Samson 2010, 2013; Bright 2003; Morsink 2006).

In terms of settlement location all sites are situated on the shore or are within several kilometres of the coast (max. $13 \mathrm{~km}$ ), often on elevated landscape features such as hilltops or artificial mounds. In general settlements are positioned to exploit diverse terrestrial and marine resources and access to shelter, often sited near coral reefs and caves. Those settlements on the Atlantic coasts are more exposed than those on the Caribbean coast, and those on larger islands, or those on islands with greater elevations experience more precipitation than lower, smaller islands.

\section{The Houses of El Cabo}

The indigenous town site of $\mathrm{El} \mathrm{Cabo} \mathrm{in} \mathrm{the} \mathrm{eastern}$ Dominican Republic exemplifies many of these characteristics. The extensive excavations at the site have doubled the number of indigenous structures known from the Greater Antilles. Researchers from the Museo del 


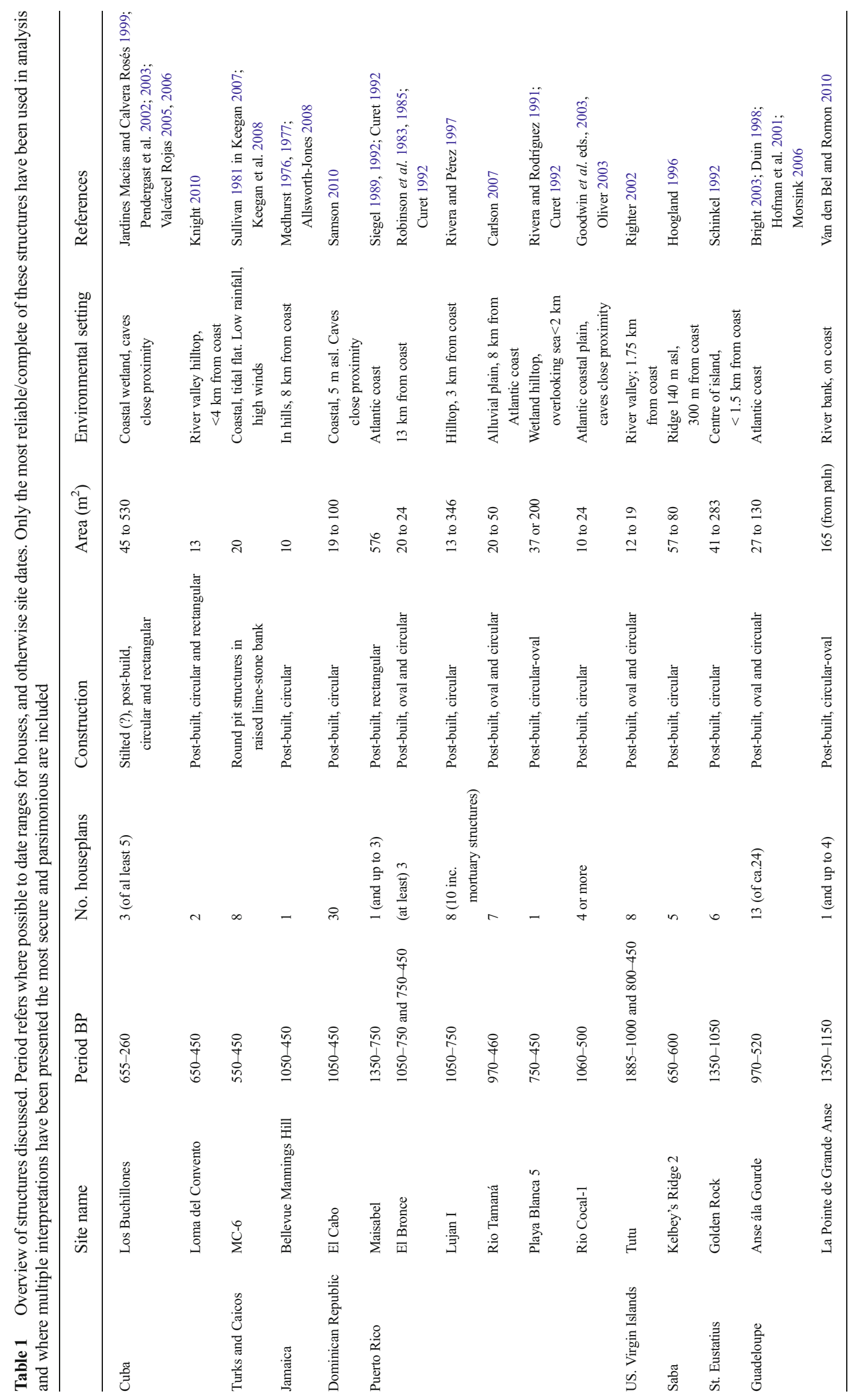


Hombre Dominicano first investigated the El Cabo site in the late 1970s, and again between 2005 and 2008 in partnership with Leiden University. ${ }^{4}$ The goal of the research in El Cabo was to develop an archaeological perspective on the indigenous house and settlement dynamics (Hofman et al. 2006, 2008; Samson and Hoogland 2007; Samson 2010, 2011). These aims were pursued by a horizontally extensive fieldwork strategy that documented habitation features, domestic structures and settlement space.

El Cabo is situated on a coastal promontory surrounded by coastal caves a kilometre inland and overlooking the Mona Passage to Puerto Rico, waves breaking over a coral reef a short distance offshore. Excavation of the main unit $\left(1000 \mathrm{~m}^{2}\right)$ revealed over 2000 archaeological features. The overwhelming majority of these features are postholes, the unique preservation of which, directly cut into the limestone bedrock, enabled identification of over 50 structures, 30 of which are houses, in addition to a platform structure, storerooms for community regalia, fences or palisades, windbreaks and work huts. From 1100BP to around a decade after European colonization El Cabo was a town consisting of some half a dozen neighbouring groups of houses arranged along the coast. Individual houses were periodically rebuilt, or renewed. The archaeological traces of this process are sequences of multiple, contiguous, overlapping house-plans, or House Trajectories (Samson 2010: fig.152). Individual house structures were circular, between 6.5 and $10 \mathrm{~m}$ in diameter, and consisted of an outer perimeter wall of closely-spaced, slender posts, and eight, larger, roof-bearing posts, aligned on an inland facing doorway (Fig. 3). House structures $(n=31)$ share specific architectural features, are consistently larger and more symmetrical in plan than other structures $(n=21)$, are associated with certain types of artefacts and ritual practices, and were rebuilt multiple times.

The archaeological evidence attests to the multifunctional character of the house, in which domestic spaces were also social and political institutions and the location of daily activities and long-term community investments. Accumulated debris around the houses indicate the preparation and consumption of meals, pottery for cooking and serving, and tools for subsistence and craft activities; ritual objects indicate the consultation of ancestors and community ceremonies; human remains indicate mortuary rituals; and the placing of personal effects in postholes on the abandonment of the house indicate its intimate relationship with the lives of its inhabitants.

The high-resolution archaeological data from El Cabo enable an expansion of the geographic scale of analysis and a re-evaluation of structures from other sites with

\footnotetext{
${ }^{4}$ Directed by Dr Menno Hoogland, "Houses for the living and the dead, organisation of settlement space and residence rules among the Taino, the indigenous people of the Caribbean encountered by Columbus". The Netherlands Organisation for Scientific Research, project nr. 360-62-030.
}

fewer houses and for which physical data or detailed plans are lacking. The institutional durability of some of these houses, apparently over millennial timescales, is witnessed in the house trajectories, which form longlived estates whose members were likely able to trace their ancestors back to common origins (Samson 2010).

\section{The Caribbean Architectural Mode}

The plans from the sites in Table 1 belong to small, round and semi-round post built structures. Many have internal features such as hearths and in some human burials were found under the house floors. Features exterior to the structures include pathways, fences, and small ancillary buildings, interpreted as kitchens, windbreaks, and mortuary structures. Although a systematic study of these features and associated artefact assemblages would be an important step in defining whether the structures fulfilled similar roles, this is beyond the scope of the current paper. In addition to similarities in settlement location at least seven shared construction characteristics can be identified which are shared across sites and islands:

\section{Architectural Footprint}

Firstly, the majority of structures are circular to oval and use a combination of large and small posts distributed regularly throughout the building. There is a clear distinction between heavier, roof-bearing posts, and smaller wall elements. Deep foundations are a recurrent feature of Caribbean architecture (Mason 1941; Hofman et al. 2012; Schinkel 1992), although the hardness and durability of tropical hardwoods, such as mahogany and sapodilla, mean that even slender posts could have supported considerable loads. For example, $90 \%$ of postholes in El Cabo are less than $26 \mathrm{~cm}$ across, and over $25 \%$ are between 12 and $14 \mathrm{~cm}$ in diameter, which means the posts themselves were even slighter. Postholes in El Cabo fall into diameter classes that likely correspond to the most common dimensions for construction timbers, suggesting standardization and availability of suitable trees. The same may not have been the case for smaller islands such as the Turks and Caicos where high winds and lack of rainfall may have limited availability of suitable timbers. This is indicated by structures on MC-6, which rely on stone construction material probably in addition to timber. Walls of woven vines (bejucos), or open walls would have allowed breeze to circulate inside structures, with the use of windbreaks to mitigate strong gusts and provide sheltered areas to work in and around houses (evidence for which is found in Tutu, Golden Rock, El Cabo, and Anse à la Gourde).

European roundhouse studies indicate that structures up to $12 \mathrm{~m}$ in diameter have no need of internal roof supports (Pope 2008). Nevertheless, even though most of the Caribbean 
Fig. 3 3D rendition of the plan of house Structure 1, El Cabo, Dominican Republic. Note the internal symmetries of the plan: the two close-set entrance postholes align on an internal configuration of eight paired posts, probably supporting tie-beams and a ring beam. The entrance is flanked by alternating larger and smaller postholes of decreasing size, with smaller postholes in the back of the house. The prevailing easterly wind would have been channelled over the roof creating a sheltered outdoor space in front of the house

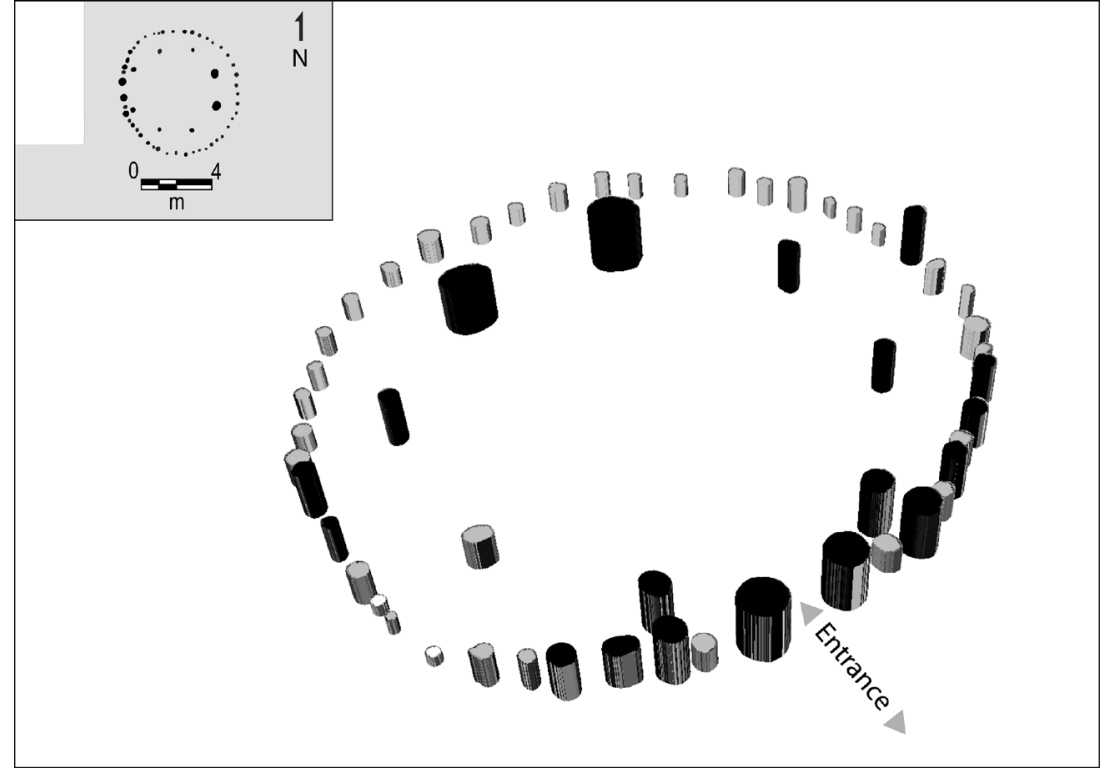

structures are considerably smaller, numerous solutions are adopted for supporting the roof: by the external wall, internal post rings or sometimes a central post (s). Structures from several sites in Puerto Rico share the same heavier four-post framework incorporated into the outer wall - a pattern first remarked upon by Rivera and Rodríguez (1991) for Playa Blanca 5 (Curet 1992) and occurring more frequently at El Bronce and Río Cocal-1. Four-post central configurations occur at several sites across the Caribbean at Río Tanamá (Structure 6), Luján I and Tutu (Structures 2 and 7), Anse à la Gourde (multiple structures), La Pointe de Grande Anse (locations 1 and 2) and Kelbey's Ridge 2 (structures 1 to 4). Elsewhere, such as Los Buchillones and El Cabo, inner post rings provide roof support. A centre post (s) is not standard, occurring only in some structures in less than half of sites.

\section{Size}

Overall, houses are small structures, which fall most credibly within the range of 20 to $60 \mathrm{~m}^{2}$, with an average area of $54 \mathrm{~m}^{2}$ (Fig. 4). Using Antonio Curet's formula for estimating prehistoric populations (1998) this equates to four to eleven inhabitants per structure, which may represent a small extended family, or imply the distribution of members of an extended household over multiple structures.

In terms of chronological variation, there are currently neither enough radiocarbon dates nor a body of reliable early plans to identify trends. A reported decrease in house size over time for eastern Puerto Rico, referred to earlier, needs to be tested with more comparative, regional datasets (Curet 1992; Curet and Oliver 1998). In terms of geographic distribution, size variation occurs within and between sites. Houses in the Greater Antilles are on average smaller than in the Lesser
Antilles. The largest size category contains several structures from sites in the northern Lesser Antilles including the three maloca-style houses from Golden Rock. In general, houses in all periods in the study region are considerably smaller than ethnographic examples from the South American mainland and archaeological examples from the southern Caribbean islands and mainland (Schinkel 1992:184; Oliver 1995; Versteeg and Rostain 1997).

\section{High-Pitched Roofs}

Thirdly, houses probably had high-pitched roofs. This is suggested for Tutu, Playa Blanca 5, Golden Rock and El Cabo. Archaeological evidence from $\mathrm{El} \mathrm{Cabo} \mathrm{indicates} \mathrm{the} \mathrm{roof-}$ pitch for Type 1 houses was $40^{\circ}$ based on the incline of the postholes of the outside wall, which also formed the roof (Samson 2010:239). At Golden Rock, Schinkel calculates roof pitch as a steep $0.8 \times$ diameter (1992: 192).

\section{Monumental Facades}

Fourth, house facades may have been reinforced and emphasized. This is most apparent in the case of El Cabo where large posts either side of the entrance run up to a third of the perimeter of the house, becoming smaller and shallower towards the back (Fig. 3). All house structures in El Cabo and three from Tutu (Structures 1, 2 and 6) have either double or enlarged entrance features. This can be seen in Fig. 5, which shows two structures from El Cabo with characteristic narrow, but monumentalized westerly entrances, and a structure from Tutu with an east-facing portico represented by doubled postholes (Righter 2002:316). Although not explicitly stated by excavators, the plans indicate that structures at the sites of Luján I 
Fig. 4 Histogram showing the frequency of house floor areas. This table excludes five larger structures from Cuba (Los Buchillones, $530 \mathrm{~m}^{2}$ ), Puerto Rico (Maisabel, $576 \mathrm{~m}^{2}$, Luján I, $346 \mathrm{~m}^{2}$ ) and Haiti (En Bas Saline, two oval plans $15 \mathrm{~m}$ diameter) due to their incompleteness or lack of published details

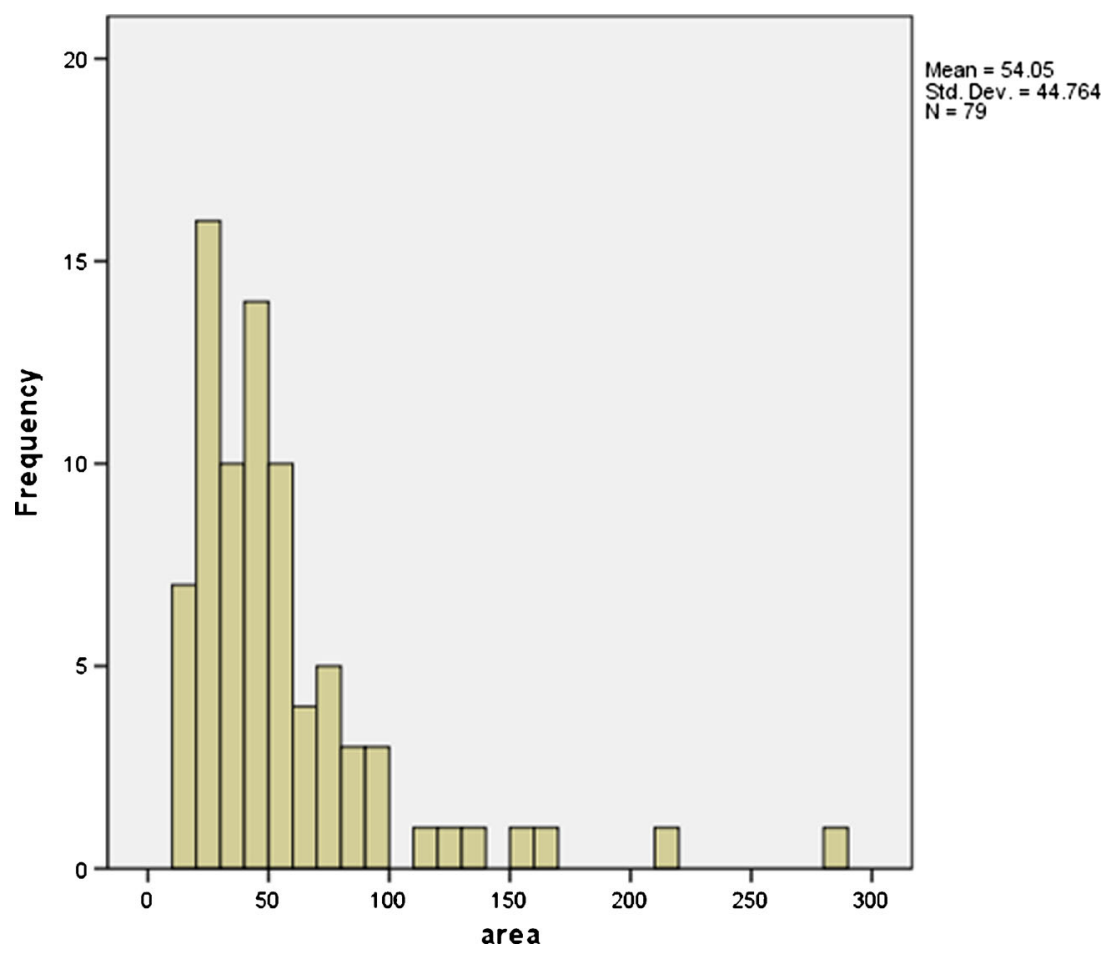

(Structures 1, 6 and partial 7) and Río Tanamá (Structure 2) may have had doorways consisting of paired, heavy-set posts. In the case of Luján I these entrance features appear to align on internal configurations, as in El Cabo, and open onto a central clearing (Rivera and Pérez 1997). ${ }^{5}$ In general doorways are narrow and low, admitting one person at a time and perhaps requiring the individual to duck. It is not clear whether the structures from the Lesser Antilles share this feature.

\section{Prepared Floors}

Fifth, there is evidence for prepared floors. In some sites creating a level living surface was relatively easy, whereas in others it required significant effort. At Playa Blanca, for example, an irregular surface was cleared and levelled by removing rubble and rocks, and in Kelbey's Ridge 2 the gravel of the house floors had been compacted. In El Cabo, rather than concentrating building activities in areas of softer, sandy deposits, the hard, uneven peaks of the limestone had been removed to form a flat surface inside structures.

\section{Securely Anchored Foundations}

Sixth, there is a preference across the region for selecting the bedrock for securing house foundations (Table 2). Where this is the case, either a select number of the larger posts are anchored

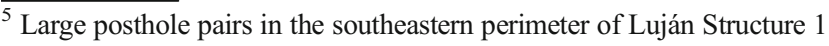
and the western perimeter of Structure 6 can be discerned in Fig. 5; however, without publication of further details this remains tentative.
}

in the limestone or volcanic bedrock, such as at Anse à La Gourde and Golden Rock, or the majority of the postholes are bored directly into the bedrock. This is the case in El Cabo where postholes ranging from a few centimetres to well over a metre deep are hewn into hard limestone. These features are extremely regular in plan and cross-section, probably closely correlated to timber dimensions, and must have been made with great skill using perhaps shell picks or chisels (Fig. 6). An alternative means of anchoring structures is seen at MC-6 on Middle Caicos where stone-lined, semi-pit circular structures were set in raised limestone banks (Keegan 2007).

Despite the fact that there is currently little evidence for regular contact between the south eastern United States and the Caribbean islands in prehistory, we nevertheless include two sites from what is today downtown Miami in this discussion because of the striking similarities in terms of the physical characteristics and technological choices (Wheeler and Carr 2004; Collins et al. 2006). Although ostensibly dating to over 500 years earlier than the Caribbean houses, the coastal setting of the sites and their overlapping, concentric and regular circular structures in the upper size range of the Caribbean house floors $\left(106 \mathrm{~m}^{2}\right)$, with postholes cut into limestone bedrock, are quite at home in the tradition of the bedrock architecture of the islands.

\section{Durability: Repair and Rebuilding}

Lastly, it appears many structures endured a considerable length of time through either rebuilding or the replacement of parts. This characteristic longevity was already observed 
Fig. 5 House plans from top left to bottom right: El Cabo (structures 4 and 14, black), Tutu (structure 2, grey), Anse à la Gourde (structure 2, black) and Luján (structures 1 and 6, white)
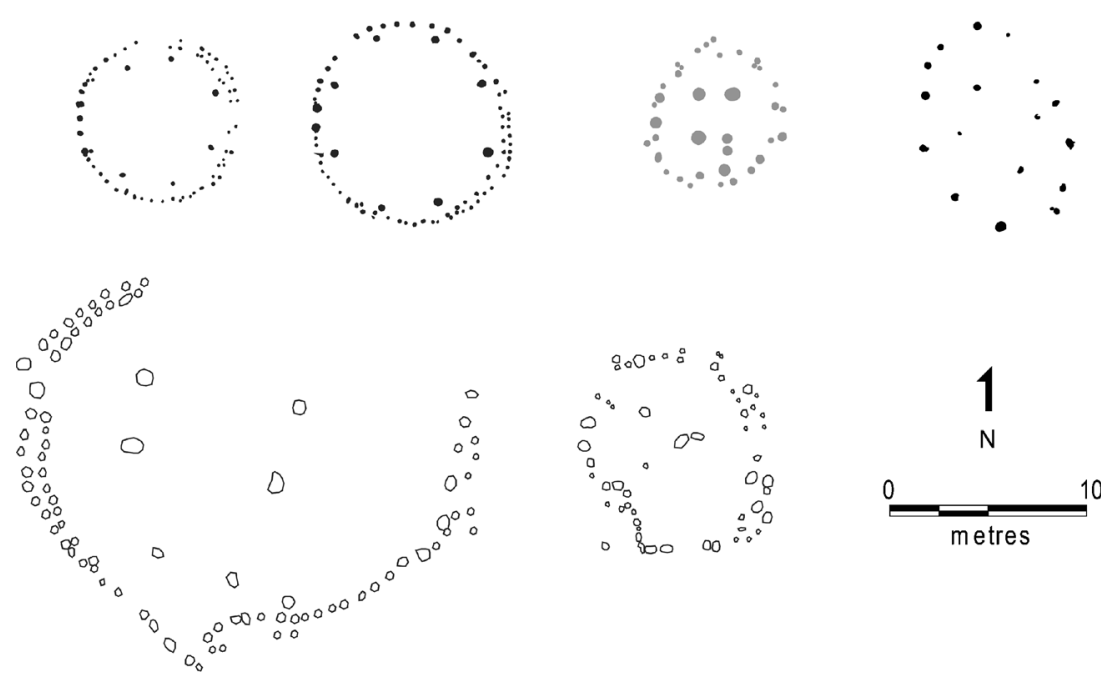

for settlements in the northern Lesser Antilles by Versteeg et al. (1993) and Schinkel ( 1992) and contrasted with shorter-lived villages in the South American lowlands.

Figure 5 shows rebuilding and repair in the doubling of features of the perimeter walls of structures in El Cabo, and we suggest, along the back walls in Luján I. Replacement of structural elements and evidence for repair can be seen at most sites. One of the most striking examples of longevity through repair is house 1 from Los Buchillones, Cuba, with a lifespan of 360 years (Pendergast et al. 2002).

Site occupation typically spans several centuries with the number and spatial distribution of features often relating to two and up to five related building phases. This is indicated by the feature clustering at sites such as Tanamá, Luján I, Maisabel, Río Cocal-1, El Bronce, Tutu, Golden Rock, Anse à la Gourde and La Pointe de
Grande Anse, and particularly exemplified by the house trajectories in Kelbey's Ridge 2 and El Cabo with an eleventh century date for one of the first houses, and fifteenth century colonial material directly related to the last house in a related sequence at the latter site.

These data from many house plans and sites show that common house features appear in the archaeological record after 1400BP. The emergence of this mode coincides with widespread transformations in indigenous society of which these changes were a part. By 1100BP a process of house definition and elaboration was well underway which enhanced people's capacity to carry out daily tasks, gain political and institutional leverage, transmit memory, and deal with the environment, similar to the role of the house in non-industrial societies worldwide (Beck ed. 2007; Joyce and Gillespie 2000).
Table 2 Sites with postholes cut into the bedrock

\begin{tabular}{lll}
\hline & Sites & References \\
\hline Cuba & Loma del Convento & Knight 2010 \\
& El Morillo & Hernández and Rodríguez 2008 \\
Dominican Republic & El Cabo & Samson 2010 \\
& Macao & Andújar Persinal et al. 2004:171 \\
& Caletón Blanco & Olsen Bogaert 2001, 2002 \\
& Soco & pers. comm. Veloz Maggiolo \\
Puerto Rico & Playa Blanca 5 & Rivera and Rodríguez 1991 \\
& Luján I & Rivera and Pérez 1997 \\
St. Eustatius & Golden Rock & Schinkel 1992 \\
Guadeloupe & Anse á la Gourde & Bright 2003; Duin 1998; \\
& & Hofman et al. 2001; Morsink 2006 \\
Florida, U.S.A. & La Pointe de Grande Anse & Van den Bel and Romon 2010 \\
& Miami Circle & Wheeler and Carr 2004 \\
& Palm Royal Circle & Collins et al. 2006; \\
& & Wheeler and Carr 2004 \\
\hline
\end{tabular}


Fig. 6 Postholes cut into the bedrock in Anse à la Gourde, Guadeloupe (left), and El Cabo, Dominican Republic (right). Note the regularity of the features
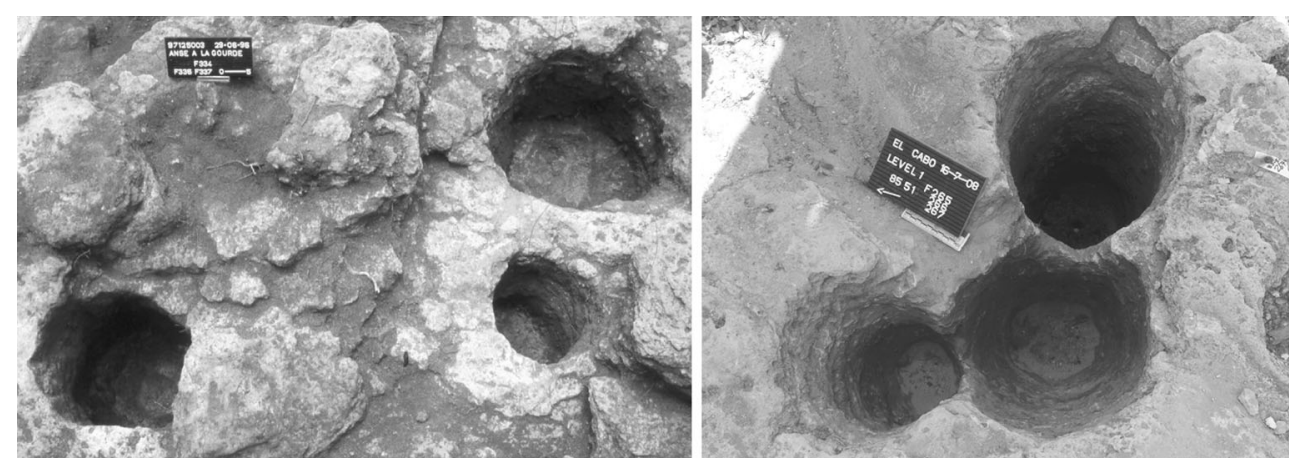

The house both constituted changes and catalysed opportunities to make things possible.

\section{Discussion}

\section{Geographic Scales and Timeframes of Interest: Modes Shared by People Across a Region and Over Time}

These regional data show that indigenous communities across the Caribbean, and arguably further afield, shared and developed house-building strategies comprising small, carefully designed and evenly anchored structures with high-pitched roofs and reinforced facades. These common features emerged in areas with similar ecologies and were well adapted for dealing with the winds, precipitation and heat of the Caribbean. Settlement characteristics such as the irregular layout of houses and the use of windbreaks and partitions reduced exposure to wind. Lastly houses experienced centuries of longevity due to deliberate prolongation of their lives through rebuilding and repair.

\section{Perspectives on Change: Rates and Means of Repairing and Rebuilding}

These long-range data suggest that houses would have performed well both surviving an event and in speed of reconstruction (supporting Cooper and Peros 2010). The foundations were secure in high winds and earth tremors, in part because long, dense timbers are heavy enough to resist uplift. ${ }^{6}$ Making postholes in the bedrock would have facilitated house

\footnotetext{
${ }^{6}$ Uplift is the vertical upward force from wind lifting out foundations this is a result of the suction effect of a lower wind pressure on the leeward face of a shelter or roof surface. Transitional Shelters supplied in Haiti after the 2010 earthquake (rectangular $5 \mathrm{~m} \times 4 \mathrm{~m}$ in plan) were designed with blocks of 0.2 to 0.3 cubic metres of concrete as foundations that would weigh enough to resist uplift. For a Category 1 hurricane (108 mph or $43 \mathrm{~m} / \mathrm{s}$ gust speeds), calculated uplift forces on these shelters varied between $4 \mathrm{kN}$ (corners) $7 \mathrm{kN}$ (middle post). Depending on the height, strength of connections and permeability of the walls and roof of the El Cabo houses, uplift would be of a similar order and mahogany posts (density of $660 \mathrm{~kg} / \mathrm{m} 3$ or about a third of concrete) with the diameters and depths recorded would indeed resist uplift forces of 3 to $4 \mathrm{kN}$ at the monumental façade and an average of 1.75 for the other 52 posts.
}

dismantlement at the approach of extreme events (the main posts could be laid flat); kept intact the most valuable and labour-intensive parts of the construction (large support posts and foundations); and allowed rapid repair and reuse after initial storm impact (posts could be reassembled in the original foundations). The same postholes may have been reused multiple times for multiple replacements of the same house (Fig. 7). Moreover, as has been noted for Los Buchillones, the shedding of building materials would cause relatively little harm to inhabitants (Cooper and Peros 2010). Ease and speed of dismantlement may also have favoured smaller rather than larger houses, and the choice of smaller, and thus more numerous dwelling structures may have increased building survivorship ratios. Houses thus incorporated and shared a "sacrificial principle" by virtue of their combination of robust and replaceable lightweight elements providing an effective recovery system. It is this technology which European colonizers misinterpreted as expedient and insubstantial.

The means of prolonging house life - repair, dismantlement, reusable post-holes and replaceable elements - do not in themselves explain why house trajectories endured. Instead, these data show frequent, cyclic adaptations to the weather, infrequent fundamental change over time, and when change does occur, it is for multiple complex reasons. The mode persisted, in the terminology of McGlade (1995), even as instabilities and tensions were playing out at generational, seasonal and daily timescales, exhibiting its ability to both absorb and utilise change at different scales, from climatic variability to periodic storms, and the waxing and waning of family groups to political upheavals and wider social change. A theory of change, on this evidence, must consider the house as both social process and (technological) product in which no pathway predictably arrives at a stable, fully explicable or permanent house.

\section{Treatment of the Evidence: Unknowable Motives for Repairing and Rebuilding}

The data confirm one mode's effectiveness at mediating the environment: evidence for other modes and other factors influencing building choices is beyond the scope of this paper. 
Fig. 7 Repair and rebuilding in the lifecycle of a house. 1) digging foundations, 2) construction, 3) habitation \& cycles of repair, 4) abandonment and re-use of parts, 5) ritual closing, 6) starting anew. Based on Samson 2010; fig 155

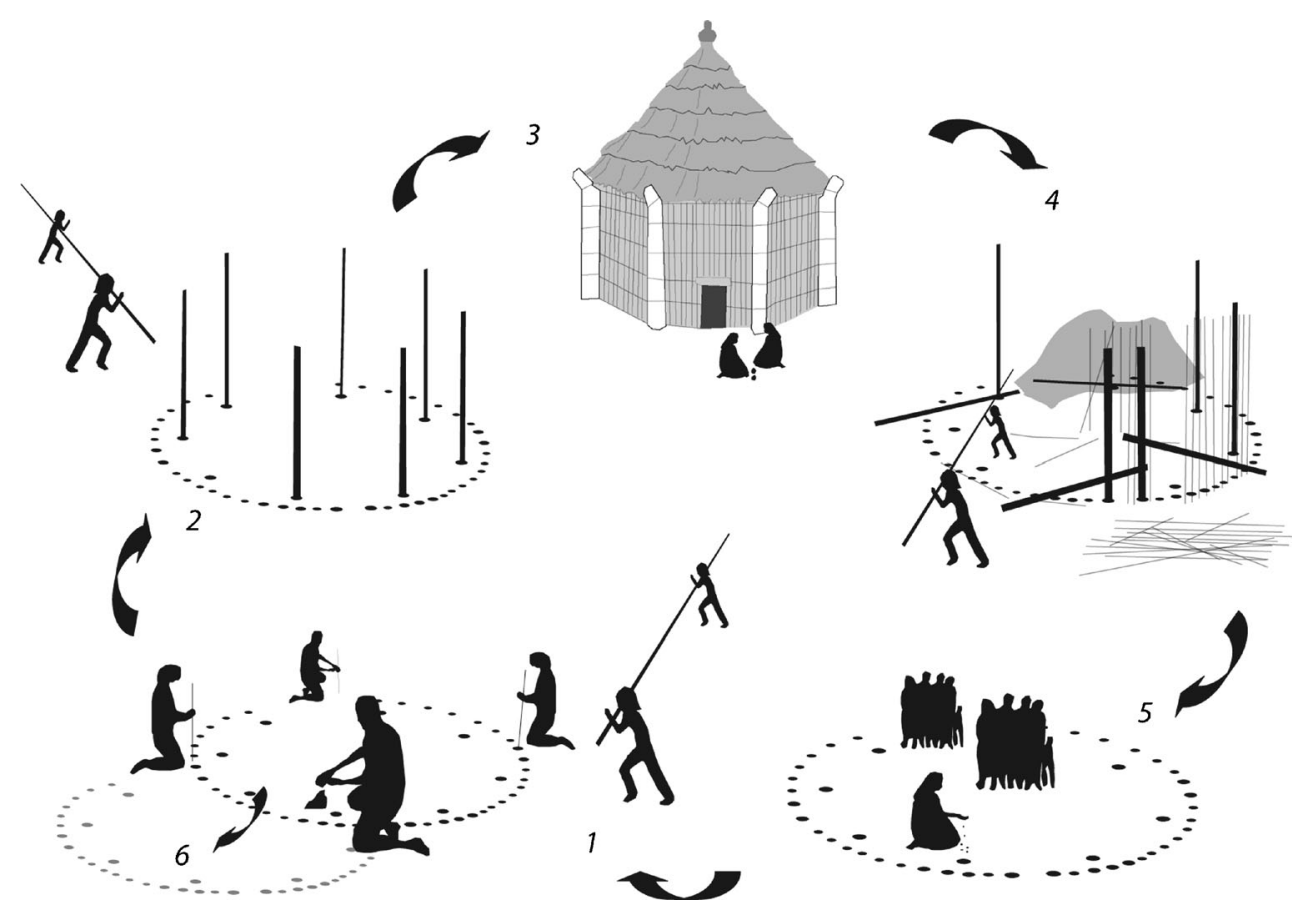

Even within the mode, the variation between sites shows there was no natural template, rather the mode's characteristics were contingent upon and encoded in diverse ecological and nonecological relations. For example, house form expressed cosmological principles (Siegel 2010); house size corresponded to patterns of household mobility and demography (Curet 1992; Veloz Maggiolo 1984); settlement location was a trade-off between proximity to neighbours and resources, and exposure to climate risk (Keegan et al. 2008; Cooper and Peros 2010); roof height and elaborate facades played a role in exhibition (Pané 1999) and signified the identities and affinities of house members; and digging foundations, the selection of materials, and house construction structured community lifecycles. In El Cabo, despite the fact that postholes in the bedrock offered the possibility of infinite re-use, inhabitants periodically built new foundations, possibly as part of coordinated periods of community renewal - a choice that cannot be reduced to functionalist explanations.

The archaeological data presented here offer a time-depth lacking in contemporary humanitarian responses, complement studies of past human-environment relations by focusing on individual structures, and examine house building technologies that are shaped both by maritime ecologies and by shared cultural practices that made the house central to community identity and practice.

The emergence, formalization and persistence of this particular Caribbean building mode experienced less frequent fundamental change over time than humanitarian conceptualisations of shelter might predict, and instead exhibits certain useful features and more cyclic adaptation to the weather.
Ultimately, we hope that considering this long-term, regional analysis of house features might contribute to greater engagement between archaeologists and those responsible for building (or rebuilding) the present.

Acknowledgments Thank you to the Museo del Hombre Dominicano for collaboration on the site of El Cabo, to the Netherlands Organisation for Scientific Research and the Faculty of Archaeology, Leiden University for supporting the archaeological research. Kate Crawford's postdoctoral post at the Department of Civil, Environmental and Geomatic Engineering at University College London was funded by the Engineering and Physical Sciences Research Council.

Open Access This article is distributed under the terms of the Creative Commons Attribution 4.0 International License (http:// creativecommons.org/licenses/by/4.0/), which permits unrestricted use, distribution, and reproduction in any medium, provided you give appropriate credit to the original author(s) and the source, provide a link to the Creative Commons license, and indicate if changes were made.

\section{References}

Allsworth-Jones, P. (2008). Pre-Columbian Jamaica. Caribbean Archaeology and Ethnohistory. The University of Alabama Press, Tuscaloosa.

Andújar Persinal, C., Guerrero, J. G., Olsen Bogaert, H., and Jiménez Lambertus, A. (2004). 2. Investigaciones. Resumen de Gestión Para El Museo Del Hombre Dominicano 2000-2004. 4. Arqueología de Macao. Boletín Del Museo Del Hombre Dominicano 37: 171.

Beck R. A., ed. (2007). The Durable House: House Society Models in Archaeology. Carbondale Archaeological Investigations. Carbondale: Center for Archaeological Investigations, Occasional Paper no. 35, Southern Illinois University.

Beets, C. J., Troelstra, S. R., Grootes, P. M., Nadeau, M.-J., van der Borg, K., de Jong, A. F. M., Hofman, C. L., and Hoogland, M. L. P. 
(2006). Climate and Pre-Columbian Settlement at Anse à La Gourde, Guadeloupe, Northeastern Caribbean. Geoarcheology 21: 271-80.

Bérard, B., Kleffer, G., Raynal, J. P., and Vernet, G. (2001). Les Eruptions Volcaniques de La Montagne Peleé et Le Premier Peuplement de La Martinique. In Alofs, L., and Dijkhoff, R. A. C. F. (eds.), XIX International Congress for Caribbean Archaeology. Museo Arqueológico de Aruba, Aruba.

Bhattacharjee A., Jacob P. M., Sumasundaram M., Ramachandran R., Thileepan S., Kumar S., Srikantharajah S., and Suppiah, L. (2007). Final Evaluation of CARE Australia Supported Tsunami Response in Trincomalee and Batticaloa Districts of Sri Lanka. CARE Australia and CARE Sri Lanka.

Boomert, A. (1999). "Saladoid Sociopolitical Organisation." In Proceedings of the XVIIIth International Congress for Caribbean Archaeology, 55-77. Association Internationale d'Archéologie de la Caraibe, St George, Grenada.

Boomert A. (2000). Trinidad, Tobago and the Lower Orinoco Interaction Sphere: An Archaeological/Ethnohistorical Study. PhD thesis, Carri Publications, Alkmaar: Leiden University.

Bright, A. J. (2003). Spatial Dynamics and Social Development in the Northern Lesser Antilles - a Pilot Study Based on Settlement Structure at the Site of Anse à la Gourde, Guadeloupe. MA thesis: Leiden University, Leiden.

Burnell, J., and Sanderson, D. (2011). Whose Reality Counts?: Shelter after Disaster. Environmental Hazards 10(3-4): 189-92.

Carlson L. A. (2007). 7. Descriptions of Archaeological Features in AR38. A Multidisciplinary Approach to Site Testing and Data Recovery at Two Village Sites (AR-38 and AR-39) on the Lower Río Tanamá, Municipality of Arecibo, Puerto Rico. Final Report. U.S. Army Corp of Engineers. Southeastern Archaeological Research, Inc.

Clermont C., Sanderson D., Sharmu A., and Spraos, H. (2011). Urban Disasters - Lessons from Haiti: Study of Member Agencies' Responses to the Earthquake in Port Au Prince, Haiti, January 2010, Report for the Disasters Emergency Committee (DEC)". Disasters Emergency Committee.

Collins, L., Doering, T., and Carr, R. S. (2006). Integrated Spatial Technologies: High Definition Documentation of the Miami Circle and Royal Palm Circles. The Florida Anthropologist 59: 161-78.

Cooper, J. (2012). Fail to Prepare, Then Prepare to Fail: Rethinking Threat, Vulnerability, and Mitigation in the Precolumbian Caribbean. In Cooper, J., and Sheets, P. (eds.), Surviving Sudden Environmental Change. Answers from Archaeology. University Press of Colorado, Boulder, pp. 91-114.

Cooper, J. (2013). The Climatic Context for Pre-Columbian Archaeology in the Caribbean. In The Oxford Handbook of Caribbean Archaeology. Oxford University Press, Oxford, pp. 47-60.

Cooper J., and Peros, M. (2010). The Archaeology of Climate Change in the Caribbean. Journal of Archaeological Science.

Crawford, C. A. (2011). Can Humanitarian Responses in Urban Areas Reinforce Underlying Causes of Vulnerability? Tweaking a Livelihoods Analysis of Inequality and Infrastructure in Splintering Cities. Environmental Hazards 10(3-4): 327-45.

Crawford, K., Bolanos, S., Rossetto, T., Kohler, S., Coates, K., Flinn, B., and Barritt, P. (2013). "Technical Evidence after Disasters: A Review of Documents from Haiti, Peru and Pakistan." Humanitarian Innovation Fund.

Curet, L. A. (1992). House Structure and Cultural Change in the Caribbean: Three Case Studies from Puerto Rico. Latin American Antiquity $3: 160-74$

Curet, L. A. (1998). New Formulae for Estimating Prehistoric Populations for Lowland South America and the Caribbean. Antiquity 72: 359-75.
Curet, L. A., and Oliver, J. R. (1998). Mortuary Practices, Social Development, and Ideology in Precolumbian Puerto Rico. Latin American Antiquity 9: 217-39.

Da Silva, J. (2010). Lessons from Aceh: Key Considerations in PostDisaster Reconstruction. Practical Action.

Davis, I. (1978). Shelter after Disaster. Oxford Polytechnic Press, Oxford.

Davis, I. (2011). What Have We Learned from 40 Years' Experience of Disaster Shelter?". Environmental Hazards 10(3-4): 193-212.

Delpuech A. (2004). Espaces Naturels et Territories Amérindiens Dans La Caraïbe Orientale. In Late Ceramic Age Societies in the Eastern Caribbean, edited by C. L. Hofman and André Delpuech. BAR International Series 1273/Paris Monographs in American Archaeology 14

Delpuech, A., Hofman, C. L., and Hoogland, M. L. P. (1997). Fouilles Sur Le Site Précolombien de l'Anse À La Gourde (Saint-François, Guadeloupe). Journal de La Société Des Américanistes 83: 279-82.

Donnelly, J. P., and Woodruff, J. D. (2007). Intense Hurricane Activity over the Past 5,000 Years Controlled by El Niño and the West African Monsoon. Nature 447: 465-68.

Drewett, P. L., and Bennell, M. (2000). "Settlement Archaeology on Barbados II: The Port St Charles (Heywoods) Archaeological Rescue Project.”. In Drewett, P. L. (ed.), Prehistoric Settlements in the Caribbean. Fieldwork in Barbados, Tortola and the Cayman Islands. Archetype publications for the Barbados Museum and Historical society, St Ann's Garrison, St Michael, Barbados, pp. 27-50.

Duin, R. (1998). “Architectural Concepts in Caribbean Archaeology: A Preliminary Archaeological Report of the Features at Anse À La Gourde, Guadeloupe. The House in Past and Present in EthnoHistory, Ethnography and Ethno-Archaeology." Masters thesis, Leiden University, Leiden.

Fernández de Oviedo y Valdéz, G. (1851). Historia General Y Natural de Las Indias, Islas Y Tierra-Firme Del Mar Océano. Vol. 1. 5 vols. Madrid: La Reál Academia de la Historia.

Fitzpatrick, S. (2011). On the Shoals of Giants: Natural Catastrophes and the Overall Destruction of the Caribbean's Archaeological Record. Journal of Coastal Conservation 14(1): 1-14.

Fitzpatrick, S. M., and Keegan, W. F. (2007). Human Impacts and Adaptations in the Caribbean Islands: An Historical Ecology Approach. Earth and Environmental Science Transactions of the Royal Society of Edinburgh 98: 29-45.

Goodwin, R. C., Oliver, J. R., Davis, D. D., Brown, J., Sanders, S., and Simmons, M. (2003). Archaeological Survey and Evaluation of Sites at NSWC Sabana Seca: Evaluation of Prehistoric Site Río Cocal-1 Site. United States Department of the Navy, Atlantic Division, Naval Facilities Engineering Command, Norfolk, VA.

Heckenberger M. J., and Petersen J. B. (1995). Human Interactions and Population Movement in the Caribbean Basin. Concentric Circular Village Patterns in the Caribbean: Comparisons from Amazonia. In Proceedings of the XVIth International Congress for Caribbean Archaeology, 379-389. Basse Terre.

HERR. (2011). Humanitarian Emergency Response Review. Independent Review Panel Chaired by Lord (Paddy) Ashdown.

Hernández de Lara, O., and Rodríguez Tápanes, B. E. (2008). Consideraciones En Torno a Una Posible Estructura de Vivienda En El Asentamiento Aborigen El Morrillo, Matanzas, Cuba. Comechingonia Virtual: Revista Electrónica de Arqueología 1: $24-42$.

Hodell, D. A., and Curtis, J. H. (1991). Reconstruction of Caribbean Climate Change over the Past 10,500 Years. Nature 352: 790.

Hofman, C. L. (2013). "The Post-Saladoid in the Lesser Antilles (AD 600/800-1492).”. In Keegan, W. F., Hofman, C. L., and Rodríguez Ramos, R. (eds.), The Oxford Handbook of Caribbean Archaeology. Oxford University Press, Oxford, pp. 205-220. 
Hofman C. L., and Bright A. J. eds. (2010). Mobility and Exchange from a Pan-Caribbean Perspective. Special Publication 3. Journal of Caribbean Archaeology.

Hofman C. L., and Hoogland, M. L. P. (2012). Caribbean Encounters: Rescue Excavations at the Early Colonial Island Carib Site of Argyle, St. Vincent. In Bakels, C., and Kamermans H (eds). Analecta Praehistorica Leidensia 43/44:63-76.

Hofman, C. L., and Hoogland, M. L. P. (2015). "Beautiful Tropical Islands in the Caribbean Sea. Human Responses to Floods and Droughts and the Indigenous Archaeological Heritage of the Caribbean.". In Willems, W. J. H., and Schaik, H. (eds.), Water and Heritage: Material, Conceptual and Spiritual Connections. Sidestone Press, Leiden, pp. 99-119.

Hofman, C. L., and Hoogland, M. L. P. (1999). Archaeological Investigations on St. Martin (Lesser Antilles): The Sites of Norman Estate, Anse Des Pères and Hope Estate with a Contribution to the "La Hueca Problem". Vol. 4. Archaeological Studies Leiden University. Faculty of Archaeology, Leiden University, Leiden.

Hofman, C. L., and Hoogland, M. L. P. (2010). Interim Report on the Results of the 2009 (May and June) Rescue Excavations at the Lavoutte Site (Cas-En-Bas), St. Lucia. Faculty of Archaeology, Leiden.

Hofman, C. L., Hoogland, M. L. P, and Delpuech, A. (2001). Spatial Organisation at a Troumassoid Settlement, the Case of Anse À La Gourde, Guadeloupe. Proceedings of the 19th Congress of the International Association for Caribbean Archaeology, 124 31.

Hofman, C. L., Hoogland, M. L. P., Mickleburgh, H. L., Laffoon, J. E., Field, M. F., and Weston, D. A. (2012). Life and Death at Lavoutte, Saint Lucia, Lesser Antilles. Journal of Field Archaeology 37: 20925.

Hofman, C. L., Hoogland, M. L. P., Oliver, J. R., and Samson, A. V. M. (2006). Investigaciones Arqueológicas En El Cabo, Oriente de La República Dominicana: Resultados Preliminares de La Campaña de 2005. El Caribe Arqueológico 9: 95-106.

Hofman, C. L., Hoogland, M. L. P., Samson, A. V. M., and Oliver, J. R. (2008). Investigaciones Arqueológicas En El Cabo, Oriente de La República Dominicana: Resultados Preliminares de Las Campañas 2005 y 2006. Boletín Del Museo Del Hombre Dominicano 42: 30716.

Hoogland, M. L.P. (1996). In Search of the Native Population of PreColumbian Saba (400-1450 A.D.). Part Two. Settlements in Their Natural and Social Environment. PhD dissertation, Leiden: Leiden University.

Hoogland, M. L. P., and Hofman, C. L. (1993). Kelbey's Ridge 2, A 14th Century Taíno Settlement on Saba, Netherlands Antilles. Analecta Praehistorica Leidensia 26: 164-81.

Jansen, R., and Dorst, M. C. (2007). Spatial Patterning and Structures of the Multi-Component Ceramic Age Site San 1, Manzanilla, Trinidad. In Basil, R (ed), Proceedings of the Twenty-First Congress of the International Association for Caribbean Archaeology, University of the West Indies, School of Continuing Studies, St. Augustine, 1:315-27.

Jardines Macías, J., and Calvera Rosés, J. (1999). "Estructuras de Viviendas Aborígenes En Los Buchillones.”. El Caribe Arqueológico 3: 44-52.

Joyce, R. A., and Gillespie, S. D. (2000). Beyond Kinship: Social and Material Reproduction in House Societies. University of Pennsylvania Press, Philadelphia.

Kaplan, J. (2009). The Excavation, Analysis, and Comparison of Structural Configurations in the Feature Exposure Trench-12 Area at Site PO-29: Phase III Data Recovery Efforts for the Portugués Dam and Pool Project, Ponce, Puerto Rico. MA thesis, Leiden: Leiden University.
Keegan, W. F. (2007). Taino Indian Myth and Practice: The Arrival of the Stranger King. Ripley P. Bullen Series. Florida Museum of Natural History.

Keegan, W. F., Fitzpatrick, S. M., Sealey, K. S., LeFebvre, M. J., and Sinelli, P. T. (2008). The Role of Small Islands in Marine Subsistence Strategies: Case Studies from the Caribbean. Human Ecology 36: 635-54.

Knight, V. J. (2010). La Loma Del Convento: Its Centrality to Current Issues in Cuban Archaeology. In Kepecs, S., Curet, L. A., and La Rosa Corzo, G. (eds.), Beyond the Blockade: New Currents in Cuban Archaeology. University of Alabama Press, Tuscaloosa, pp. 26-46.

Langenbach, R. (2009). Don't Tear It Down! Preserving the Earthquake Resistant Vernacular Architecture of Kashmir. Oinfroin Media.

Langenbach, R., Kelley, S., Sparks, P., Rowell, K., Hammer, M., and Olsen, J. J. (2010). World Monuments Fund. In Avrami, E. (ed), Preserving Haiti's Gingerbread Houses: 2010 Earthquake Mission Report.

Langenbach, R., Mosalam, K. M., Akarusu, S., and Dusi, A. (2006). Armature Crosswalls: A Proposed Methodology to Improve the Seismic Performance of Non-Ductile Reinforced Concrete Infill Frame Structures. In Proceedings of the 8th U.S. National Conference on Earthquake Engineering. San Francisco, California.

Las Casas, Bartolomé de. (1875). Historia de Las Indias. Vol. 1.4 vols. Madrid: Imprenta de Miguel Inesta.

Lyons, M., Schilderman, T., and Sanderson, D. (2011). Harnessing Time: Reflections on Constraints to Development. Environmental Hazards 10(3-4): 213-17.

Malaizé, B., Bertran, P., Carbonel, P., Bonnissent, D., Charlier, K., Galop, D., Imbert, D., Serrand, N., Stouvenot, C., and Pujol, C. (2011). Hurricanes and Climate in the Caribbean during the Past 3700 Years BP. The Holocene.

Mason, J. A. (1941). A Large Archaeological Site at Capá, Utuado, with Notes on Other Porto Rico Sites Visited in 1914-1915. (with an Appendix by I. Rouse on Artifacts). In Scientific Survey of Porto Rico and the Virgin Islands, 18:2:209-65. New York Academy of Sciences.

McGlade, J. (1995). Archaeology and the Ecodynamics of HumanModified Landscapes. Antiquity 69: 113-32.

Medhurst, C. W. (1976). The Bellevue Site. Archaeology Jamaica 3: 3 12.

Medhurst, C. W. (1977). Bellevue (K13) Phase II. Archaeology Jamaica 3(1-9): 12-19.

Meléndez Maíz, M. J. (1996). Mitigación Arqueológica Del Yacimiento de Barrazas, Carolina (Fase III - Etapa III). Inform Final Que Incorpora Los Resultados de Las Temporadas de Excavación de 1992 Y 1994 (fase III - Etapas I, II, Y III). Centro de Servicios Múltiples de Barrazas, San Juan.

Morsink, J. (2006). "(Re-)Constructing Constructions: Quotidian Life and Social Practice at Anse à La Gourde." MPhil thesis, Leiden University, Leiden.

Oliver, J. R. (1995). A Prehistoric Longhouse Structure (FAL-7) in Maticora Valley, Western Venezuela. In Proceedings of the XVIth International Congress for Caribbean Archaeology, 134-57. Basse Terre.

Oliver, J. R. (2003). An Interpretative Analysis and Discussion of the Río Cocal-1 Community of Sabana Seca, Puerto Rico. In Goodwin, R. C., Oliver, J. R., Davis, D. D., Brown, J., Sanders, S., and Simmons, M. (eds.), Archaeological Survey and Evaluation of Sites at NSWC Sabana Seca: Evaluation of Prehistoric Site Río Cocal-1 Site, IV (parts I-II). United States Department of the Navy, Atlantic Division, Naval Facilities Engineering Command, Norfolk, VA, pp. 337-402.

Olsen Bogaert, H. (2001). Adendum Prospección Arqueológica. Estudio de Impacto Ambiental Proyecto: Concesión de Explotación Minera Carmelo. Consorcio Empaca-Redes, Secretaría de Estado de Medio 
Ambiente y Recursos Naturales, Higüey, Provincia La Altagracia. Santo Domingo.

Olsen Bogaert, H. (2002). Rescate Arqueológico: Proyecto Turístico Inmobiliario Cap Cana, Juanillo, Higuey, La Altagracia. Museo del Hombre Dominicano, Santo Domingo.

Pain, A., and Levine, S. (2012). A Conceptual Analysis of Livelihoods and Resilience: Addressing the "insecurity of Agency." HPG Working Paper. ODI.

Pané, R. (1999). An Account of the Antiquities of the Indians: A New Edition with an Introductory Study, Notes and Appendixes by José Juan Arrom. Translated by Susan C. Griswold. Durham, NC: Duke University Press.

Pendergast, D., Graham, E., Rosés, J. C., and Macías, J. J. (2002). The Houses in Which They Dwelt: The Excavation and Dating of Taino Wooden Structures at Los Buchillones, Cuba. Journal of Wetland Archaeology 2: 61-75.

Pendergast, D., Graham, E., Rosés, J. C., and Macías, J. J. (2003). Construcciones de Madera En El Mar. Los Buchillones, Cuba. El Caribe Arqueológico 7: 24-42.

Petitjean Roget, H. (2001). Contribution À l'Etude Du Troumassolde et Du Saladoide (600-1200 AD). Une Hypothèse Sur Les Causes de La Regression Du Saladoide Aux Petites Antilles. In Proceedings of the 19th International Congress for Caribbean Archaeology, edited by L. Alofs and R.A.C.F. Dijkhoff, 227-38. Aruba: Museo Arqueologico Aruba.

Pielke, R. A. Jr., Rubiera, J, Landsea, C., Fernandez, M. L., and Klein, R. (2003). Hurricane Vulnerability in Latin America and The Caribbean: Normalized Damage and Loss Potentials. Natural Hazards Review.

Pope, R. E. (2008). Roundhouses: 3,000 Years of Prehistoric Design. Current Archaeology 222: 14-21.

Redman, C. L. (2012). Global Environmental Change, Resilience, and Sustainable Outcomes. In Cooper, J., and Sheets, P. (eds.), Surviving Sudden Environmental Change. Answers from Archaeology. University Press of Colorado, Boulder, pp. 237-44.

Redman, C. L., and Kinzig, A. P. (2003). Resilience of Past Landscapes: Resilience Theory, Society, and the Longue Durée. Conservation Ecology 7.

Richards, S. (2012). 'Vernacular' Accommodations: Wordplay in Contemporary-Traditional Architecture Theory. Arq: Architectural Research Quarterly 16(01): 37-48.

Righter, E. (Ed.)(2002). The Tutu Archaeological Village Site: A Multidisciplinary Case Study in Human Adaptation. Routledge, London and New York.

Rivera, V., and Pérez, S. A. (1997). "Estudio Preliminar de La Distribución Espacial En La Comunidad Aborígen de Lu Juan 1." In Proceedings of the Seventeenth Congress of the International Association for Caribbean Archaeology, edited by Winter, J. H., 266-81. Rockville Center, New York.

Rivera, V., and Rodríguez, M. (1991). The Playa Blanca 5 Site: A Late Prehistoric Ceramic Site in Eastern Puerto Rico (A Preliminary Report). In Ayubi, E. N. and Haviser, J. B, (eds), Proceedings of the Thirteenth International Congress for Caribbean Archaeology, 2:541-58. Reports of the Archaeological-Anthropological Institute of the Netherlands Antilles.

Robinson, L. S., Lunberg, E. R., and Walker, J. B. (1983). Archaeological Data Recovery at El Bronce, Puerto Rico: Final Report, Phase 1. U. S. Army Corps of Engineers, Jacksonville District, Jacksonville, Florida.

Robinson, L. S., Lunberg, E. R., and Walker, J. B. (1985). Archaeological Data Recovery at El Bronce, Puerto Rico: Final Report, Phase 2. U. S. Army Corps of Engineers, Jacksonville District, Jacksonville, Florida.

Rodríguez Ramos, R. (2010). Rethinking Puerto Rican Precolonial History. In Caribbean Archaeology and Ethnohistory. The University of Alabama Press, Tuscaloosa.
Roobol, M. J., and Smith, A. L. (2004). Volcanology of Saba and St. Eustatius, Northern Lesser Antilles. Royal Netherlands Academy of Arts and Sciences, Amsterdam.

Samson, A. V. M. (2010). Renewing the House: Trajectories of Social Life in the Yucayeque (community) of El Cabo, Higüey, Dominican Republic, AD 800 to 1504. Sidestone Press, Leiden. https:// openaccess.leidenuniv.n1/handle/1887/15288.

Samson, A. V. M. (2011). The Most Beautiful House in the World: The Archaeology of Aesthetics in Eastern Hispaniola. In Hofman, C. L., and van Duijvenbode, A. (eds.), Communities in Contact. Essays in Archaeology, Ethnohistory and Ethnography of the Amerindian Circum-Caribbean. Sidestone Press, Leiden, pp. 421-38.

Samson, A. V. M. (2013). "Household Archaeology in the PreColumbian Caribbean.”. In Keegan, W., Hofman, C. L., and Rodríguez Ramos, R. (eds.), The Oxford Handbook of Caribbean Archaeology. Oxford University Press, Oxford.

Samson, A. V. M., and Hoogland, M. L. P. (2007). Residencia Taína: Huellas de Asentamiento En El Cabo, República Dominicana. El Caribe Arqueológico 10: 93-103.

Scheffers, A., Scheffers, S., and Kelletat, D. (2005). Paleo-Tsunami Relics on the Southern and Central Antillean Island Arc. Journal of Coastal Research 263-73.

Schilderman, T., and Lyons, M. (2011). Resilient Dwellings or Resilient People? Towards People-Centred Reconstruction. Environmental Hazards 10(3-4): 218-31.

Schinkel, K. (1992). "The Features of Golden Rock.”. In Versteeg, A. H., and Schinkel, K. (eds.), The Archaeology of St. Eustatius: The Golden Rock Site. The St. Eustatius Historical Foundation/The Foundation for Scientific Research in the Caribbean Region, St. Eustatius/Amsterdam, pp. 143-212.

Siegel, P. E. (1989). Site Structure, Demography, and Social Complexity in the Early Ceramic Age of the Caribbean. In Early Ceramic Population Lifeways and Adaptive Strategies in the Caribbean, 506:193-245. Oxford: BAR International Series.

Siegel, P. E. (1992). Ideology, Power and Social Complexity in Prehistoric Puerto Rico. PhD thesis, Binghampton: State University of New York.

Siegel, P. E. (1996). Ideology and Culture Change in Prehistoric Puerto Rico: A View from the Community. Journal of Field Archaeology 23: 313-33.

Siegel, P. E. (2010). Continuity and Change in the Evolution of Religion and Political Organization on Pre-Columbian Puerto Rico. Journal of Anthropological Archaeology 29: 302-26.

Siegel, P. E., and Righter, E. (2011). Protecting Heritage in the Caribbean. Caribbean Archaeology and Ethnohistory. University of Alabama Press.

Sphere Project. (2004). Humanitarian Charter and Minimum Standards in Disaster Response. The Sphere Project.

Sullivan, S. (1981). The Colonization and Exploitation of the Turks and Caicos Islands, British West Indies. PhD dissertation, UrbanaChampaign: University of Illinois.

Torres, J. M. (2012). The Social Construction of Community, Polity, and Place in Ancient Puerto Rico (AD 600 - AD 1200). PhD dissertation, Gainesville: University of Florida.

Tsunami Evaluation Coalition. (2006). Links between Relief, Rehabilitation and Development in the Tsunami Response. TEC. http://www.alnap.org/pool/files/lrrd-final-report.pdf.

United Nations Office for the Coordination of Humanitarian Affairs. (2004). A Guide to the Use and Logistics of Family Tents in Humanitarian Relief. OCHA/ESB/2004/19. United Nations Publication.

Valcárcel Rojas, R. (2005). Informe de Excavación Arqueológica En El Conjunto de Postes D2-6, En E1 Sitio La Laguna, Área Arqueológica de Los Buchillones, Ciego de Ávila, Cuba. Holguín. 17. art 50. 
Válcarcel Rojas, R., Rosés, J. C., Martínez, O. B., and Labrada, M. (2006). Postes En El Mar: Excavación de Una Estructura Constructiva Aborigen En Los Buchillones. El Caribe Arqueológico 9: 76-88.

Van den Bel, M., and Romon, T. (2010). "A Troumassoid Site at TroisRivières, Guadeloupe FWI Funerary Practices and House Patterns at La Pointe de Grande Anse.”. Journal of Caribbean Archaeology 9: $1-17$.

Veloz Maggiolo, M. (1984). La Arqueología de La Vida Cotidiana: Matices, Historia Y Diferencias. Boletín de Antropología Americana Del Instituto Panamericano de Geografia E Historia 10: 5-21.

Veloz Maggiolo, M. (1991). Panorama Historico Del Caribe Precolombino. Banco Central de la República Dominicana, Santo Domingo.

Versteeg, A. H., and Schinkel, K. (1992). The Archaeology of St. Eustatius: The Golden Rock Site. The St. Eustatius Historical Foundation/The Foundation for Scientific Research in the Caribbean Region, St. Eustatius/Amsterdam.
Versteeg, A. H., and Rostain, S. (1997). The Archaeology of Aruba: The Tanki Flip Site. Publications of the Archaeological Museum Aruba 8 Publications of the Foundation for Scientific Research in the Caribbean Region 141. Aruba and Amsterdam: Archaeology Museum Aruba.

Versteeg, A. H., Schinkel, K, and Wilson, S. M. (1993). Large-Scale Excavations versus Surveys: Examples from Nevis, St. Eustatius and St. Kitts in the Northern Caribbean. Analecta Praehistorica Leidensia : Publications of the Institute for Prehistory of the University of Leiden 26: 139-61.

Walker, J. (2005). The Paso Del Indio Site, Vega Baja, Puerto Rico: A Progress Report. In Siegel, P. E. (ed.), Ancient Borinquen: Archaeology and Ethnohistory of Native Puerto Rico. The Uni versity of Alabama Press, Tuscaloosa, pp. 55-87.

Wheeler, R. J., and Carr, R. S. (2004). The Miami Circle: Fieldwork, Research and Analysis. The Florida Anthropologist 57: 310 . 